\title{
The Strategy of Improving Complaint Management in Surakarta City Toward Society 5.0-Based Public Service
}

\author{
Hana Ni'ma Rosida ${ }^{1}$, Kristina Setyowati ${ }^{2}$ \\ ${ }^{1}$ Universitas Sebelas Maret (email: nima9hana@student.uns.ac.id) \\ ${ }^{2}$ Universitas Sebelas Maret (email: kristina@staff.uns.ac.id)
}

\begin{abstract}
The organization of public service is not free of public critique. The management of complaint is a factor that can improve public service quality. Complaining is important because it is the public's expression that can result from public dissatisfaction with a product or a service. Moreover, to deal with Society 5.0 era, the government should provide a system to solve the problem. Therefore, this research aims to discuss the strategies taken by Surakarta City Government in managing complaint in Surakarta City toward a society 5.0-based public service. This research employed a qualitative research method. Technique of analysis used in this study was content analysis technique obtained through literature review. Based on the result of literature review, it can be seen that some strategies have been taken by Surakarta City Government, including, among others: improving the quality of human resource constituting public apparatuses; making policy; and providing complaining media.
\end{abstract}

\section{Keywords:}

complaint management; public service; society 5.0; Surakarta City

\section{Introduction}

Public service is the state's obligation to organize the fulfillment of basic needs and civil rights to product, service, and administration service provided by the public service provider for every citizen. Public service is important to organize, because it is related to the public (wide society) with diverse interests and purposes. It is in line with the 1945's Constitution mandating the state to fulfill the basic needs of every Indonesian citizen in order to achieve welfare and to fulfill the rights in the framework of public service. And, the $4^{\text {th }}$ paragraph of Preamble of 1945 Constitution firmly states that the objective of Republic of Indonesia state establishment is, among others, to promote public welfare and to educate the nation life. The organizer of public service in Indonesia is compared with a state's organ, like Central Government and Local (Provincial, Regency, Municipal) Government. Particularly in society 5.0 era, public service is very crucial. To give law certainty in the relation between 
community and the organizer of public service and to confirm the fulfillment of public service to citizens, government establishes Public Service Law. Law No. 25 of 2009 about Public Service is the law governing the principles of good governance constituting the effectiveness of governmental functions themselves. Public service organized by government or corporation can effectively strengthen democracy and human rights, promote economic prosperity and social cohesion, reduce poverty, improve environmental protection, utilize natural resource wisely, and increase the trust in government and public administration.

Society 5.0 era is the one in which technology becomes a part of human beings, internet no longer serves as informant but also lives human life. The main component of Society 5.0 is human beings who can create new values through technology development that can minimize the gap between human beings and economic problem in the future life. This idea attempts to encourage and to explain digital community with some limits and to create digital reality; this concept aims to promote the potential relation between individual and technology (Serpa \& Ferreira, 2018). For that reason, people can solve various challenges and social problems through utilizing various innovations born in Industrial Revolution 4.0 era such as Internet on Things, Artificial Intelligence, Big Data, and robot to improve the quality of human life. Society 5.0 can also be defined as a concept of technology-based community.

In organizing public service, public satisfaction is the main goal of the successful public service organization, particularly in Society 5.0 era. This satisfaction can be brought into reality if the service provided is compatible to the standard service specified. Standard service is a measure that has been determined as a standardization of good service, by considering service quality. The quality service will be the parameter for the performance of governmental institution (Faozan2013). In its organization, public service is inseparable from public critique, because the performance of public apparatus has not been satisfactory yet. PATTIRO study, as cited in Utomo (2006), found that the poor response or feedback from the institution providing service to the public grievance or complaint leads to skepticism within the community. Responding to this, government should provide a system to solve the problem. It is in line the Republic of Indonesia's Law No. 23 of 2014 about Local Government and Presidential Regulation Number 76 of 2013 about the Management of Public Service Complaint. 
Actually, the management of complaint also has obvious legislative policy. It has been governed in the Republic of Indonesia's Law Number 23 of 2014 about Local Government and Presidential Regulation Number 76 of 2013 about the Management of Public Service Complaint. For that reason, governmental institution, particularly local government can provide conflict management as soon as possible to its public. It is this that is done by Surakarta City in implementing the complain management policy. Despite obvious regulation, many governmental institutions have not implemented yet the complaint management policy. It is because many governmental institutions are still confused with how to implement the policy and complaint is often considered as bad things to the life of public service provider, so that many parties attempt to hide or to ignore it. Even many people do not how to express their grievance to the governmental institution (Sudrajat:2011). Most people also have not known and understood yet that in public policy the people are entitled to express complaint or to give input to the service they have received.

Complaint, according to Yuliarmi and Riyasa (2017), is public's expression likely resulting from the public's dissatisfaction with a product or service. People tend to complain when they feel that the complaint expressed is responded to positively and does not take time and cost. Complaint should also be seen as a right to express opinion, and every Indonesian citizen has the right. Complaint management is one of ways or instruments to improve the relationship between government and its people, in order to create public service that is transparent, responsive, and accountable. For that reason, the complaint management should get serious attention from public apparatus.

Article 1 clause 8 of Mayor of Surakarta City' Regulation Number 29 of 2019 states that the public complaint management is a process of activity involving receiving, recording, studying, clarifying, channeling, following-up, reporting, and archiving the public complaint. Complaint management, according to Bappenas (2010), is system, mechanism, and procedure of managing grievances or protests likely coming from many parties in structured manner, thereby not generating agitation and disturbing the smoothness of work and the performance of corresponding institution. Factors supporting the availability of complaint management are policy, leaders' commitment, planning, education level, and socialization. In addition, the successful complaint management is also affected by personal, leadership, work team, system, and contextual factors or the need at that time. In complaint management, there should be 
good management. Bappenas (2010) explains that public complaint management consists of four aspects. Firstly, basic principles include, among others, the answer to question "Whom it serves?", control over source and public complaint inflow; control over institution's response; basic attitude in receiving the public complaint. Secondly, the elements of complaint management consists of complaint source or origin, content, complaint management unit, feedback given to respond to the complaint, and report of complaint management. Thirdly, the form of complaint. Lastly, complaining channel is divided into two: internal and external channels.

The Minister of State Apparatus Utilization and Bureaucratic Reform's Regulation No. 15 of 2014 about Guidelines of Service Standard mentions that each of public service organizer (provider) should obligatorily establish and apply Public Service Standard for each type of service. The guideline of Service Standard included in the appendix in the Minister of State Apparatus Utilization and Bureaucratic Reform's Regulation No. 15 of 2014 mentions some service standards. The standards include, among others, the service providing institution required obligatorily to make the complaint management mechanism, for example, providing suggestion box or complaint box, SMS, complaint portal at website, and complaint receiving officer. Complaint management should have its own procedure, including officer name, phone, email address, and address of institution that can be contacted. All of these are component that should exist compulsorily in every public service institution.

Law No. 23 of 2014 about Local Government mentions that Local Government has an obligation to manage public complaint management issue. In addition, the public is also invited to participate and to supervise the organization of public service, development, and societal activities. Local government is obliged to build public service, including public complaint management, information management, and internal supervision. DPRD (Local Legislative Assembly) should take part in accommodating and following up public aspiration and complaint and be authorized to govern itself the regulation about the procedure of public complaint and sanction imposition. Article 352 of Law No.23 of 2014 mentions that public is entitled to complain related to the organization of public service to local government, Ombudsman, and/or Local Legislative Assembly. Then, the local leader should obligatorily implement the Ombudsman's recommendation as the follow-up of public complaint. Through this law, the complaint management is an important factor that should be prepared 
by public service institution, particularly institution managing service directly to society. Complaint management system is assessed as the form of service accountability in providing service to the community that should be conducted to encourage the improvement of service system.

Recently, complaint service has evolved in Surakarta City. However, although innovation has developed widely, in fact innovation made has not been maximal yet. For example, Surakarta City also uses complaint application called LAPOR!. LAPOR! application has been established as National Public Service Complaint Management System (SP4N) in the Presidential Regulation Number 76 of 2013 and Minister of State Apparatus Utilization and Bureaucratic Reform Number 3 of 2015. The application is intended to facilitate the public access to one complaint channel that has been integrated nationally. In addition, there are ULAS (Surakarta Complaint Service Unit) and SAPA (Aspiration and Complaint Service Channel). SAPA is a platform specifically intended for the applicant to complain to the licensing service of Surakarta City. Nevertheless, many people still complain that these applications are not as expected, related to slow feedback, difficult reporting, some confusing feature, too many platforms provided, and etc.

Considering the background of problem existing, this article will give a description concerning the importance of public participation in the improvement of public service through the public complaint management. And we can also see the strategies the local government, particularly Surakarta City Government, has taken in developing complaint management in order to achieve the quality of Society 5.0-based Public Service. Therefore, the problem statement of this research is related to the Strategy of Improving Complaint Management in Surakarta City in the attempt of improving Public Service toward Society 5.0 Era.

\section{Methods}

Research method is systematic and organized way and procedure to investigate a certain problem intended to acquire information to be used as solution to the problem (Silalahi \& Ulber, 2010). Considering the problem discussed, the type of research used was qualitative one. This qualitative research is the one describing an event according to the reality or the condition existing. Danaee fard in Shahrzad, Leila, and Roxaneh (2011) states that qualitative 
research method is developed to help the author comprehends human beings and their social culture. This research used a descriptive qualitative approach because the author wants to find out and to understand information relevant to the focus of research. Information can be descriptive data including writing, words, and document coming from source or informant studied. Thus, the author attempts to explain the Racism against Chinese Ethnic in Surakarta during Covid-19 pandemic.

This research took place in Surakarta City. This location was chosen because the service management in Surakarta public institution is the object that would be studied by the author. The research was conducted for 3 (three weeks) from July $11-25,2021$. The data source of research was secondary one, including article, literature, journal, book, official website, and etc. Data source, according Nur Indrianto and Bambang Supomo (2013:142), is an important factor becoming the material of consideration in determining the method of collecting data, in addition to type of data aforementioned. Therefore, it can concluded that data source is the most important factor in determining the method of collecting data to find out where the subject of data come from. Data source is divided into two: primary and secondary data. Technique of collecting data used was literature review. Literature review is to study various reference books and the finding of previous similar studies useful to get theoretical condition concerning the problem to be studied (Sarwono, 2006). Research journals were obtained through various sources, obtained through among others google search, google scholar (https://scholar.google.co.id/), scopus (https://www.scopus.com) and etc. the criteria of articles or journals used are both Indonesian and English journals with the topic concerning complaint management and Society 5.0. Furthermore the journals are taken as references and analyzed.

\section{Result and Discussion}

To go to Society 5.0 -based public service, some attempts need to be taken. One of them is to improve the public complaint management. Complaint management is the obligation of governmental institution that should be implemented. It is in line with Article 41 clauses 2 (f) and 3 of the Republic of Indonesia's Law Number 23 of 2014 about Local Government. In improving the complaint management, synergy is required between government, private, and community. Through providing system, procedure, and mechanism 
enabling all grievances or protests to be managed well, public service can be provided optimally. The delegation of authority from the central to the local government to govern their own region is an attempt of improving the quality of complaint management, as it is intended to cut the long bureaucratic chain.

As one of big cities in Central Java, Surakarta city has a vision to realize Surakarta as an independent, developed, and prosperous cultural city. This vision is supported with the pro-people mission. This mission is of course expected to improve the wellbeing of Surakarta people by creating opportunity of participating actively as much as possible in improving public service in Surakarta City. Surakarta City is one of very complex cities in Central java in the term of providing public facilities to its citizens, such as providing public transportation, good road facilities, open space, city forest, and etc. Regarding this, public participation is desirable for the sake of public service toward society 5.0.

In 2013, Surakarta City has issued Mayor of Surakarta's Regulation Number 25 of 2013 about Surakarta Public Complaint Service Unit in Surakarta City Government. This Mayor of Surakarta's regulation contains the regulations related to complaint management in Surakarta and of course the Public Complaint Service Unit (ULAS). It indicates that Surakarta City government has begun to use electronic media as its complaint management concept to get its citizens' aspiration. For that reason, the implementation of society 5.0 begins to be visible. Surakarta City people can send recommendation, critique, and complaint to the organization of public service through facilities provided by public service institution and through website determined by Surakarta City Government. Through its website media, Public Complaint Service Unit (ULAS), Surakarta City government intends to provide space for Surakarta citizens to give critique, input, and grievance or to report the infringement occurring. In 2019, Surakarta City issued Mayor of Surakarta's regulation Number 29 of 2019 about Surakarta Complaint Service Unit in Surakarta City Government. This Mayor of Surakarta's regulation still contains the regulation of complaint management in Surakarta and of course contain Public Complaint Service Unit (UlAS), but in Mayor of Surakarta's regulation Number 29 of 2019 about Surakarta Complaint Service Unit in Surakarta City Government the regulation of complaint management and contain Public Complaint Service Unit (U1AS) is improved. It indicates that Surakarta City government indeed pays serious attention to the complaint management in Surakarta city in going to Public Service in Society 5.0 era. 
In the attempt of improving complaint management in Surakarta City toward Society 5.0-based public service, Surakarta City has certain strategies. The strategies include, among others, improving human resource, in this case the public apparatus and also improving complaint management system in Surakarta City. Complaint management itself is the reflection of New Public Service (NPS). Essentially, running public organization is not as same as running private organization. Public organization should be run just like running a democratic government. For that reason, public should be considered as citizen rather than as client or customer. As a citizen, public is considered just like the citizen duly, who has equal right and obligation. Therefore, sate apparatus should be responsive not only to customer but also to the fulfillment of public right and build trust and collaborative relation with citizens. In addition to NPS, complaint service is also the reflection of Agile governance and dynamic governance. These three paradigms are the one answering the globalization problem. Globalization guides public apparatus to keep innovating and moving quickly. For that reason, public service should be improved, one of which is complaint service. Complaint management itself should be prioritized by governmental institution in improving the quality of public service. It is because complaint service is one of precise measure for government to organize public service more transparently, responsively, and accountably.

Surakarta City Government applies Public Quantity. The first thing to do to improve conflict management in Surakarta city toward society 5.0-based public Service is to emphasize on the public accountability in public apparatus. Public accountability, according to Mahmudi (2010), is governmental obligation to manage resource, to report and to reveal any activities related to the use of public resource to the principle, and to those interested. It can be said that public accountability is the manifestation of government's responsibility as the provider of service to provide facilities in giving information to public and other constituents becoming the stakeholders. For that reason, public accountability is the improvement of internal organization and human resource itself, in which changing human resource (institution and public service) is the basic matter to be done, because human resource is the activator or the key to this public service. Therefore, Surakarta City government applies public accountability function as well as possible in order to achieve the superior quality of human resource (public apparatus). 
Public accountability is an instrument of controlling democratic process. The presence of accountability will be a control media to the holder of mandate or in this case, public apparatus. It is because there is legal apparatus consisting of legislation, so that public can know what has been decided; and the presence of policy with obvious structure, implementation, and funding; and public control will result in a mechanism enabling the public to know whether or not there is deviation in the policy of public service implementation, particularly complaint management. Public accountability can suppress power abuse rate. The presence of accountability is not only repressive but also has preventive effect. The holders of authority (power) are encouraged to think two times when they want to do some fraud, because they are aware of the imperative to make good public accountability. Public accountability will lead public service to work as maximally as possible in short time. In this case, Surakarta City government takes some attempts to improve the quality of public apparatus in Surakarta City. It can be seen from the Mayor of Surakarta's regulation Number 9-C in 2017 about Guidelines of Improvement and Adjustment of Education for Local Civil Servant; Mayor of Surakarta's Regulation Number 16-E of 2015 about Guideline of the Selection of Prospect Participants of Leadership Education and Training at $2^{\text {nd }}, 3^{\text {rd }}$, and $4^{\text {th }}$ levels. The process of improving capacity and quality of public apparatus HR in Surakarta City is conducted through competency-based mapping (talent pool), thereby can create professional public apparatus. It is intended to create a public apparatus management based on merit system. The mapping stage in Surakarta City has been conducted since 2005 and it has been implemented completely now. The first stage is profiling, to identify competency through assessment center. The second stage is placement adjustment, and the third stage is placement. The attempts following profiling are sorting corresponding to the competency the public apparatus has and improving competency corresponding to the position occupied.

Referring to Head of National Civil Service Agency's Regulation Number 19 of 2011 about General Guideline of the arrangement of need for Civil Servants, Surakarta City conducts recruitment for Civil Servants depending on the formation provided and number of formation specified by central government. The recruitment of contract worker (Worker with Contract/TKPK) is based on Mayor of Surakarta's regulation Number 26-A of 2016 about Guideline of the Provision of Worker Service with Contract in Surakarta City's Environment. TKPK is the product of local discretion with different standard of salary for respective 
education qualifications, for example: City Minimum Wage for Junior High School, 1.5 times the city minimum wage for D3 (undergraduate), and 2 times the City Minimum Wage for S1 (graduate). The recruitment of TKPK is conducted through open selection corresponding to the need of Surakarta City Government to fill in the shortage of retired public apparatus. Most TKPK come from educators or teaching staff to fill in the shortage of HR.

Surakarta City government has used E-Kinerja application aiming to optimize the implementation of organizational task and function. E-Kinerja (E-performance) is an application with performance assessment system in the form of web-based application in order to manage the workload of personnel position, process of collecting data about the achievement of performance indicator, workload of organizational unit or work unit as the basis of job achievement calculation and work incentive granting. Indicator of E-performance assessment consists of some components expected to encourage the improvement of individual public apparatuses' performance later having an implication to the performance of OPD.

In addition to improving the quality of public apparatus' performance, Surakarta City Government also develops policy. This complaint management policy is a key factor to the successful complaint management. Referring to Article 13 of Presidential Regulation Number 76 of 2013 about Public Service Complaint Management, the management of complaint becomes the indicator of the assessment on the performance of public service organization. This regulation will explain in detail the management of complaint because public service organizer should include complaining mechanism, requirement of complaint, complaint managing team, standard operating, and complaint management facility. Clause 2 of the regulation mentions that one of public service managements is public complaint management. Even, Article 17 of Presidential Regulation number 76 of 2013 about the public service complaint management mentions that complaint management is made the material of assessment on the performance of public service organization. And the performance assessment is the accountability of public service institution. For that reason, in the presence of policy related to complaint management, governmental accountability as the provider of service can be seen is visible to the people. In developing policy, three points should be considered; policy making intended to fulfill the people's varying interests and needs; used to protect the people's rights; and realizing an orderly, peaceful, quiet, and prosperous society 
life. It can be seen from the Mayor of Surakarta's Regulation Number 25 of 2013 about Surakarta Complaint Service Unit in Surakarta City Government amended with the Mayor of Surakarta's Regulation Number 29 of 2019 about Surakarta Complaint Service Unit in Surakarta City Government. From this, it can be seen that Surakarta City Government pays serious attention to the improvement of complaint management quality.

The Mayor's Regulation issued governs the mechanism of complaint management like leadership consisting of head and team member, the one that can receive directly, process, answer the summary of public complaints through ULAS, the operating procedure of complaint management, the provision of complaint facilities, appreciation and punishment to the organizers of public service who do not obey the procedure, particularly in the term of complaint management time interval. Through this policy, Surakarta City is expected to get public response more easily to the public service organization. This, in turn, will improve service quality toward society 5.0 era through improving service coming from public complaint. The policy indicates that the second strategy taken by Surakarta City Government to implement the complaint management strategy is to develop regulation relevant to the condition at that time. This presence of Mayor's regulation underlies the complaint management. Article 10 of the Mayor of Surakarta's Regulation Number 25 of 2013 mentions that:

(1) Executor should respond to complaint in the form of answer and/or action to the complaint received by the administrator of Provider Organization.

(2) Response to complaint in the form of answer and/or action intended in clause 1 is delivered no later than 2 (two) times 24 (twenty four) hours at the day since the complaint is received by Provider Organization.

(3) If the complaint is not compatible to the provider organization's task, the administrator will contact Super Administrator to do re-delegation.

(4) After the executor follows up the complaint, the administrator of provider organization responds to the complaint delivered in ULAS application.

Having improved the quality of public apparatus and policy maker, Surakarta City government determines which model will be used in the complaint management model in Surakarta city. Complaint Management model will later relate to the technical implementation of complaint management in Surakarta City. Complaint management model 
has two model applied. The first one focuses complaint management on one unit with similar function to complaint management. This first model requires the unit designated to answer and to handle all complaints coming. This unit will be responsible fully for the process of giving answer. This unit will go to substance unit when they cannot answer the complaint. In this model, the unit designated as complaint manager should have some data of responses (answers) to the questions likely posed frequently and complained by the public. In addition, the record of complaint event will be stored tidily.

The second model is to distribute the complaint management to technical and substantive unites being the source of public complaint. This model emphasizes on the presence of one organizing unit serving as the manager of complaint. The second model requires the presence of one unit serving as the organizer of data of incoming complaint and than distributing the data directly to substantive and technical units that can answer the public complaint. The complaint receiving unit will answer and redeliver the answer to the complainer directly or through the organizing unit. This second model will be more effective by using an electronic-based complaint management system. Utilizing the electronic technology, the organizing unit will provide data of complaint immediately to the unit intended. Data of incoming complaint and the data of archived complaint can be published as the transparency measure to public information.

To realize the improvement of complaint management in Surakarta City toward a society 5.0-based public service, Surakarta City Government provides some facilities the public can choose to express complaint, grievance, and critique and suggestion to the institutions in Surakarta. The implementation of public service policy, of course, requires facilities and infrastructure. In relation to the complaint management, the questions needing to be responded to are how people can express complaint, what complaint management facilities can be accessed, what is alternative available to the inaccessible complaint management facility, and how far has been the complaining process responded to by government? The complaint management facilities intended are the ones available in the complaint receiving unit in the attempt of improving the quality of society 5.0-based public service. Some facilities established by Surakarta City Government are: the uses of suggestion box, call center (phone), SMS gateway (SMS), whatsapp, social media, and website. The complaint management should be responsive to any input related to the improvement coming 
from Surakarta people, because the fast facilities can accelerate the process of improving the quality of public service.

In providing public complaining facilities, Surakarta City Government also thinks of all parties. Of course, toward the society 5.0-based public service, local government is expected to have used relevant technology along with time development. However, in reality not all people are technology literate. For that reason, Surakarta City Government keeps maintaining complaining facilities called suggestion box.

According to Indonesian Big Dictionary (KBBI), kotak saran (suggestion box) is a device to contain letter, either suggestion or recommendation. Therefore, it can be concluded that the definition of suggestion box is a device not always box-shaped containing writing concerning suggestion, recommendation, critique, and grievance from the public to the related institution. Although suggestion box is considered as outdated, this complaining facility is still viewed to be effective, recalling that the public does not need to have direct contact with the officer to express their grievance, suggestion, and opinion. For example, we can find it in Religious Affairs Office (KUA) in Surakarta City, PUSKESMAS, RSUD Moewardi (Moewardi Regional Hospital), and Regional Mental Hospital of Surakarta, Surakarta District Court.

There are a variety of complaining facilities available to the Surakarta city people. In addition to suggestion box, Surakarta City Government also provides and receiving complaint through SMS Gateaway. In principle, according to Jati\&Dwi (2008), SMS Gateway is a software applied to computer and using integrated cellular technology in order to distribute message generated through information system via SMS media handled by cellular network. This SMS Gateway is called PANDAN. PANDAN stands for Pusat Aduan Layanan Kesehatan (Healthcare Service Complaint Center). There are six formats of grievance or complaint accommodated by PANDAN: grievances related to procedure, facilities, service, administration, officer, and cost. People who want to express grievance or complaint can send SMS to 08111767700 with the available formats as shown in the table below. 
Table 1.

Complaining Format in SMS Gateaway

\begin{tabular}{|c|c|c|}
\hline Type of Grievance & SMS Format & Sample Message \\
\hline \multirow{7}{*}{$\begin{array}{l}\text { Grievance about } \\
\text { procedure }\end{array}$} & KELUHAN \#PROSEDUR & KELUHAN \#PROSEDUR \\
\hline & \#INFO KELUHAN \#LOKASI & \#Permohonan rujukan pasien \\
\hline & [GRIEVANCE \# & BPJS berbeli-belit \#Puskesmas \\
\hline & PROCEDURE \# & $B$ [GRIEVANCE \\
\hline & GRIEVANCE & \#PROCEDURE \#application \\
\hline & INFORMATION \# & for referral for BPJS patient \\
\hline & LOCATION] & is elaborate \#Puskesmas B] \\
\hline \multirow[t]{6}{*}{ Grievance about facilities } & KELUHAN \#FASILITAS & KELUHAN \#FASILITAS \\
\hline & \#INFO KELUHAN & \#Ruang tunggu panas dan \\
\hline & \#LOKASI[GRIEVANCE \# & sesak \\
\hline & FACILITIES \# GRIEVANCE & \#Puskesmas N [GRIEVANCE \\
\hline & INFORMATION \# & \#FACILITIES \#waiting room \\
\hline & LOCATION] & is hot \#Puskesmas N] \\
\hline \multirow[t]{6}{*}{ Grievance about service } & KELUHAN \#LAYANAN & KELUHAN \#LAYANAN \\
\hline & \#INFO KELUHAN \#LOKASI & \#Pelayanan Laboratorium \\
\hline & [GRIEVANCE \#SERVICE & terlalu lama \#Puskesmas $\mathrm{X}$ \\
\hline & \#GRIEVANCE & [GRIEVANCE \#SERVICE \\
\hline & INFORMATION & \#laboratory service takes too \\
\hline & \#LOCATION] & long time \#Puskesmas X] \\
\hline \multirow{10}{*}{$\begin{array}{l}\text { Grievance about } \\
\text { administration }\end{array}$} & KELUHAN & KELUHAN \\
\hline & \#ADMINISTRASI \#INFO & \#ADMINISTRASI \\
\hline & KELUHAN \#LOKASI & \#Persyaratan pelayanan pasien \\
\hline & [GRIEVANCE \# & Unit Gawat darurat terlalu \\
\hline & ADMINISTRATION \# & banyak \#RSUD K \\
\hline & GRIEVANCE & [GRIEVANCE \\
\hline & INFORMATION \# & \#ADMINISTRATION \#too \\
\hline & LOCATION] & many requirements of \\
\hline & & Emergency patient \#K \\
\hline & & Hospital] \\
\hline \multirow[t]{6}{*}{ Grievance about officer } & KELUHAN \#PETUGAS & KELUHAN \#PETUGAS \\
\hline & \#INFO KELUHAN \#LOKASI & \#Petugas laboratorium kurang \\
\hline & [GRIEVANCE \# OFFICER \# & ramah \#RS Jiwa \\
\hline & GRIEVANCE & L[GRIEVANCE \#OFFICER \\
\hline & INFORMATION \# & \#laboratory officer is less \\
\hline & LOCATION] & friendly \#L Mental Hospital] \\
\hline \multirow[t]{6}{*}{ Grievance about cost } & KELUHAN \#BIAYA \#INFO & KELUHAN \#BIAYA \#Petugas \\
\hline & KELUHAN \#LOKASI & menarik biaya tambahan \\
\hline & [GRIEVANCE \# COST \# & kepada Pasien PKMS \\
\hline & GRIEVANCE & \#Puskemas J [GRIEVANCE \\
\hline & INFORMATION \# & \#COST \#officer charges \\
\hline & LOCATION] & $\begin{array}{l}\text { additional cost from PKMS } \\
\text { patient \#Puskesmas J] }\end{array}$ \\
\hline
\end{tabular}

In addition to receiving grievance and complaint the SMS Gateway provided also receive question and information delivery from the public. The format provided for question 
is:

INFO\#TANYA\#INFO

PESAN\#LOKASI

[INFO\#QUESTION\#INFO

MESSAGE\#LOCATION]. For example, INFO\#TANYA\# Kapan akan dilaksanakan penyuluhan pencegahan covid-19varian delta\#Kelurahan Y RW G RT M [INFO\#QUESTION\# When Education about the prevention of Delta-Variant Covid-19 will be held\# Village Y RW G RT M]. Meanwhile, the format of information delivery is INFO\#INFO PESAN\#LOKASI [INFO\#INFO MESSAGE\# LOCATION]. For example, INFO\#Ditemukan kasus covid-29 varian delta. Mohon tindak lanjutnya\#Kelurahan J RW E RT U [INFO \#delta-variant Covid-19 case is found. followup Please\# Kelurahan J RW E RT U]

In addition to suggestion box and SMS Gateaway, Surakarta City Government also provides call center service. Call center is also called phone service. Just like its name, this complaint is expressed utilizing phone call. People can deliver their complaint about the problem they encounter the officers will respond to it directly or postpone it and respond to it again when they have had the answer. Governmental institution can utilize call center as an effective complaining facility. In this call center service, Surakarta city government does not facilitate one call center as the contact that can be called by the people to express their grievance. However, there are some call centers that can be called by the people to deliver critique and suggestion to the intended institution. Some call centers in each institution are presented in the table below.

Table 2.

Contact that can be called by people in delivering grievance

\begin{tabular}{|c|c|}
\hline Number & Information \\
\hline (0271) 2931669 & $\begin{array}{l}\text { Office for Communication and Informatics } \\
\text { of Surakarta }\end{array}$ \\
\hline (0271) 7464111 & Problem related to illegal levy collection \\
\hline (0271) 630124 & Education Office of Surakarta City \\
\hline (0271) 651027 & $\begin{array}{l}\text { Legal Documentation and Information } \\
\text { Network (JDIH) of (JDIH) Surakarta }\end{array}$ \\
\hline (0271) 712461 & $\begin{array}{l}\text { Local Legislative Assembly of Surakarta } \\
\text { City }\end{array}$ \\
\hline (0271) 712465 & $\begin{array}{l}\text { Local Drinking Water Company (PDAM) of } \\
\text { Surakarta }\end{array}$ \\
\hline (0271) 6792660 & Healthcare Service \\
\hline (0271) 712600 & Police of Surakarta City \\
\hline (0271) 732668 & \\
\hline (0271) 718479 & $1^{\text {st_Class TPI Immigration Office of }}$ \\
\hline (0271) 719887 & Surakarta \\
\hline 08122551001 & Regional Mental Hospital of Surakarta \\
\hline
\end{tabular}


In delivering grievance or complaint, this call center facility is different from SMS Gateway as aforementioned. SMS Gateway has specific format to deliver complaint, divided into certain groups. In this call center, people can deliver their grievance directly.

In handling the complaint in Surakarta City, the government also facilitates complaining via email. However, just like in call center, this facility is not on one center. It means that people can deliver their grievance to the email address of individual institutions.

Table 3.

Email address can be contacted by the people in delivering complaint

\begin{tabular}{ll}
\hline \multicolumn{1}{c}{ Email } & \multicolumn{1}{c}{ Information } \\
\hline info@polrestasurakarta.com & POLRESTA Surakarta (Police of \\
& Surakarta City) \\
kanim_surakarta@imigrasi.go.id & 1st-Class TPI Immigration Office of \\
& Surakarta \\
diskominfosp@surakarta.go.id & Office for Communication and \\
& Informatics of Surakarta \\
setwan.surakarta@gmail.com & Local Legislative Assembly of Surakarta \\
& City \\
rsjd_surakarta@yahoo.com & Regional Mental Hospital of Surakarta \\
\hline
\end{tabular}

In delivering complaint or grievance, email facility does not have certain format. For that reason, people can deliver their grievance independently.

The next facility provided by Surakarta City government is whatsapp. Recently, the mayor of Surakarta (Gibran Rakabuming) begins to provide complaint channel through whatsapp since March 04, 2021. Public complaint and grievance can be delivered through 081 225067 171. The grievance can be delivered openly or privately. This channel is called Lapor Mas Wali! In this facility, the mayor of Surakarta has created special team to manage Lapor Mas Wali! channel. The team serves to forward various problems from the people to the intended institution, corresponding to their main duty and function. Before the presence of Lapor Mas Wali! Surakarta City Government has used whatsapp as one of complaint management media. However, the facility provided previously is not on one center, meaning it is managed by respective institutions. For example, POLRESTA Surakarta (police of

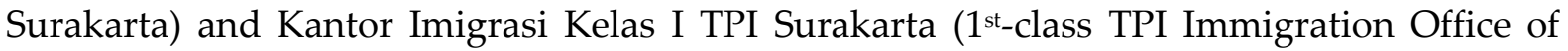
Surakarta). These two institutions can be called through 081326862626 (POLRESTA Surakarta) and 08112696999 (Kantor Imigrasi Kelas I TPI Surakarta). Despite the presence of 
Lapor Mas Wali! Channel, the whatsapp contact of individual institutions still can receive public complaint.

Recently, social media is inseparable from the people. To go to society 5.0-based public service, Surakarta City government also uses social media as one of media for Surakarta City government as a medium for Surakarta City people to deliver complaint. Even today people can deliver complaint directly through the mayor's instagram. This channel is also called Lapor Mas Wali! Just like whatsapp channel, through this Instagram channel, people can send direct message (DM) to gibran_rakabuming account. The complaint through instagram can be done either openly or privately. Of course, to manage this instagram facility, a specific team has been established. The team of instagram serves the same duty just like the team of Whatsapp, to forward various problems from the public to the corresponding institution, according to their main duty and function. Before the presence of Lapor Mas Wali! Channel, Surakarta Government also has had used instagram as one of complaining media accessible to the public. But, just like whatsapp, the message is delivered not to one account, but to individual institutions owning the account. Despite the presence of Lapor Mas Wali! channel, each of institutions still can receive the public grievance. In addition to instagram, Surakarta City Government also receives complaint through twitter and facebook. Some accounts to which the people can deliver their grievance are presented in the table below.

Table 4.

Social Media Account receiving public complaint

\begin{tabular}{lll}
\hline \multicolumn{1}{c}{ Twitter } & \multicolumn{1}{c}{ Facebook } & \multicolumn{1}{c}{ Instagram } \\
\hline @pemkot_solo & Pemkot Solo & - \\
@ulassurakarta & - & - \\
- & - & gibran_rakabuming \\
@plnsolo123 & - & - \\
\hline
\end{tabular}

Along with technology development, the media provided by Surakarta City Government in managing complaint also develops. One of complaining media facilitated by Surakarta Government is website. Through this website, Surakarta City Government begins to develop ULAS (Surakarta Grievance Service Unit). Even, ULAS has been the non-structural governmental organization units implementing public complaint service today (Articles 1-9 of the Mayor of Surakarta's Regulation Number 29 of 2019 about Surakarta Complaint Service Unit). In its practice, ULAS is under the Local Secretary of Surakarta City. According to Article 
4 of the Mayor of Surakarta's Regulation Number 29 of 2019 about Surakarta Complaint Unit, ULAS has some functions:

a. Handling the public complaint related to public policy, public service, and public official's behavior.

b. Screening complaint from complainer either passively or proactively

c. Delivering the complaint to the organizing organization to be followed up

d. Delivering the result of follow-up by the organizing organization to the reporter through ULAS or other media managed by the government

e. Delivering report to the Mayor once in 3 (three) months.

In undertaking its tasks, ULAS refers to the Mayor of Surakarta's Regulation Number 29 of 2019. ULAS complaining media consists of complaint delivery through electronic and non-electronic media. Electronic complaint can be found in website at https:/ulas.surakarta.go.id/ and twitter via id @ulassurakarta. Actually the Mayor of Surakarta's Regulation Number 29 of 2019 mentions that electronic complaint can also be delivered through mobile application. However, in implementation, only both media function. Article 9 clause 3 mentions that non-electronic complaint can delivered through other media than website, social media, and mobile application. Article 10 clause 2 mentions that the executor should respond to the complaint in the form of answer and/or action to the complaint received through the administrator of Provider Organization. Viewed from its organization, ULAS has responded to $99.9 \%$ complaints. It is shown in the web page of ULAS.

Figure 1.

\section{Appearance of website ULAS}

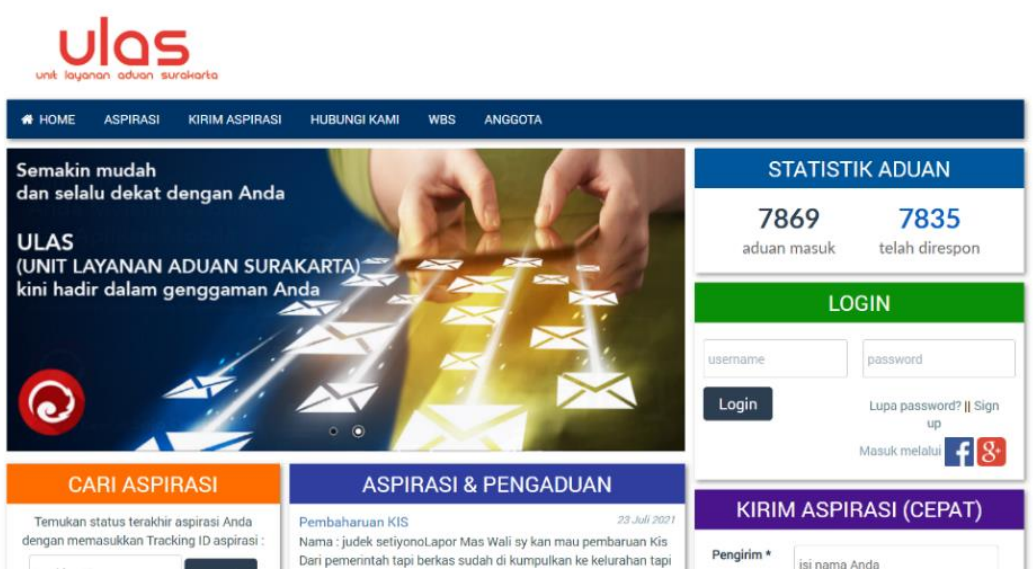


The following is the procedure of complaining through website ULAS

\section{Flowchart 1.}

\section{Procedure of Delivering Complaint in ULAS}

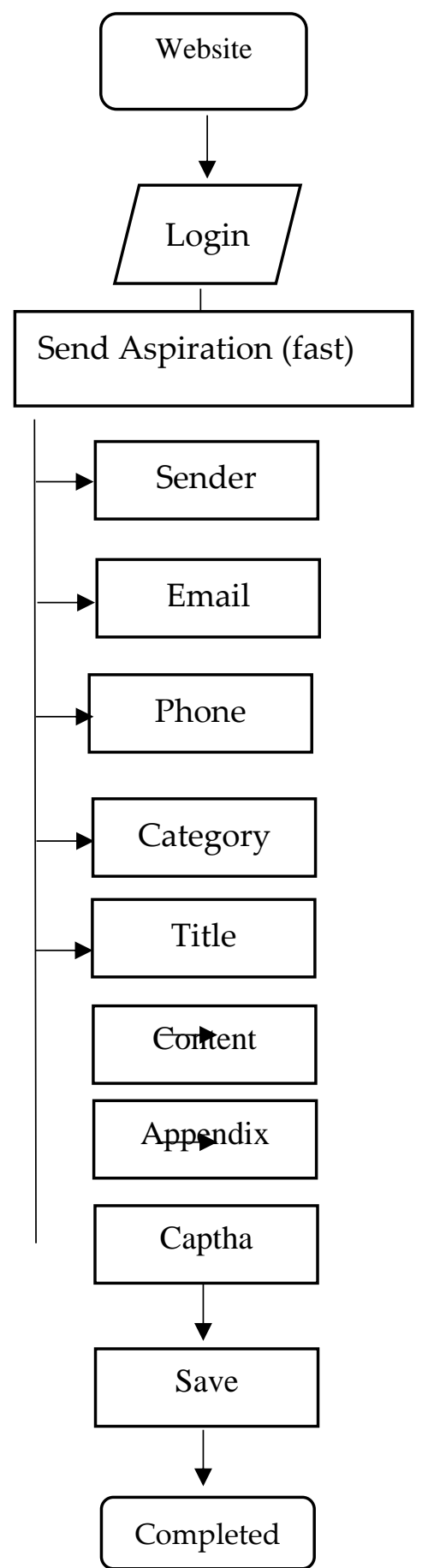

Meanwhile, the procedure of delivering complaint in twitter is that people can send their grievance by mentioning account ULAS (@ulassurakarta). There is no specific format in delivering complaint via twitter. 


\section{Conclusion}

Corresponding to the meaning of society 5.0, in which human beings live adjacently to technology, the strategies aforementioned are the measures the Surakarta City Government have taken to improve the complaint management toward the society 5.0-based public service. It can be seen from Surakarta City Government that has issued some policies: improving the quality of public apparatus and providing a variety of complaining media. Complaining media provided by Surakarta City Government also adapts to technology development, as indicated with the complaint delivery through SMS gateaway, call center, social media, whatsapp, and website. However, Surakarta City government keeps thinking of their illiterate-technology citizens by preserving suggestion box. The author recommends the Surakarta City Government to improve the quality of complaint management by increasing the facilities, particularly call center and mobile application facilities in facing Society 5.0 era. It is because these two media have not gotten much attention from Surakarta City Government.

\section{References}

Bappenas. (2010). Manajemen Pengaduan Masyarakat Dalam Pelayanan Publik. 18-19.

H, G. (2015). Analisis Model Alternatif Instrumen Pengukuran Kinerja Unit Pelayanan di Lingkungan Pemerintah Provinsi Jawa Barat. Jurnal Ilmu Administrasi, 469-490.

Hatalea, A., \& Rusmiwari, S. (2014). Budaya Kerja Pegawai Sipil . Jurnal Ilmu Sosial dan Ilmu Politik. 6-9.

Jonathan, S. (2006). Metode Penelitian Kuantitatif dan Kualitatif. Yogyakarta: Graha Ilmu.

José Sá, M. (2021). Digital Literacy in Digital Society 5.0: Some Challenges. Journal of Interdisciplinary Studies, 2-8.

Juliani, H. (2019). Upaya Strategis Pemerintah Kota Surakarta dalam Mewujudkan Profesionalisme Sumber Daya Manusia Aparatur. Journal Adminitrative Law $\mathcal{E}$ Governance , 436-447.

Martina. (2020, Mei 16). Pengertian dan Fungsi Akuntabilitas Publik (Public Accountability). Retrieved from ukirama.com: https://ukirama.com/blogs/pengertian-dan-fungsiakuntabilitas-publik-public-accountability

Pengaduan Masyarakat-Polresta Surakarta. (n.d.). Retrieved from polrestasurakarta: https://secure.polrestasurakarta.com/pengaduan/ 
Peraturan Walikota Surakarta Nomor 16-E Tahun 2015 Tentang Pedoman Penyelenggaraan Seleksi Calon Peserta Pendidikan dan Pelatihan Kepemimpinan Tingkat II, III, dan IV. (n.d.).

Peraturan Walikota Surakarta Nomor 25 Tahun 2013 Tentang Unit Aduan Layanan Masyarakat.

Peraturan Walikota Surakarta Nomor 29 Tahun 2019 Tentang Unit Aduan Layanan Masyarakat.

Peraturan Walikota Surakarta Nomor 9 Tahun 2014 Tentang Standar Operasional Prosedur pada Unit Aduan Layanan Masyarakat.

Peraturan Walikota Surakarta Nomor 9-C Tahun 2017 Tentang Pedoman Peningkatan dan Penyesuaian Pendidikan bagi Pegawai Negeri Sipil Daerah.

Retrieved from jdih.surakarta.go.id: https://jdih.surakarta.go.id/

Silalahi, U. (2010). Metode Penelitian Sosial. Bandung: Refika Aditama.

SMS Center. (n.d.). Retrieved from https://www.smscenter.net

Utomo, T., Samopa, F., \& Setiawan, B. (2012). engembangan Sistem Pengaduan Konsumen Terkait Bisnis Online Berbasis Facebook Open Graph Protocol Dan Sms Gateway. Jurnal Teknik ITS, 362-367.

Yohanitas, A. W., \& Prayitno, T. H. (2014). Pengelolaan Pengaduan Masyarakat Kota Bekasi Bekasi City Public Complaints Management. Jurnal Borneo Administrator, 328-346. 